\title{
7. PALYNOLOGY OF PALEOGENE CLAY FROM DSDP SITE 368, CAPE VERDE RISE
}

\author{
Elena D. Zaklinskaja, Geological Institute of the USSR Academy of Sciences, Moscow
}

The section at Site 368 (Cape Verde Rise) has Upper Cretaceous (Turonian?) black clay and nanno ooze and marl separated from lower Miocene marl by a thick sequence (about $640 \mathrm{~m}$ ) of green, gray-green, and red clay and silty clay that are extremely poor in organic remains. Upper Cretaceous agglutinated foraminifers (Krasheninnikov and Pflaumann, this volume) were recognized in the lower part of this sequence. Some interbeds in the clay (Samples 27, CC through 30, CC) are characterized by radiolarians (Johnson, this volume) and nannoplankton (Cepek, this volume) of early Eocene age.

Sixteen samples were examined with the aim of obtaining supplementary palynological data and establishing the Cretaceous-Paleogene boundary. Pollen of land plants and a diverse complex of microphytoplanktonic cells were found only in Sample 41-4, $11-13 \mathrm{~cm}$. The palynological complex consists of the flora of angiosperm plants (Plates 1, 2, 3). Gymnosperms are usually absent but a few rare pollen grains (Ephedripites and Cycadaceae[?]) were found. The pollen includes mainly the families Santalaceae, Lecydiaceae, Sapindaceae, Rubiaceae, Sonneratiaceae, Euphorbiaceae, Pandanaceae, Moraceae, Thimelaeaceae, Bombacaceae, Combretaceae, A pocinaceae, Nymphaeaceae, Palmaceae, Papaveraceae, Myrtaceae, Juglandaceae (Engelhardtia), and Betulaceae (Alnipollenites). The greatest diversity occurs in the Neogene and Holocene flora and these represent a flora from tropical and subtropical latitudes. The established palynocomplex characterizes a flora of the forest type and plant coenoses associated with coasts which had humid microclimates that promoted the growth of brushwoods of the mangrove type (pollen Rhizophoraceae, Sonneratiaceae, Avicenia, Nipa). The predominance of angiosperms in the assemblage indicates that the shore line was not more than several hundred kilometers from the site of deposition. Numerous marine palynological studies of coastal regions and open seas show that with distance from shore, the relative content of angiosperm pollen decreases relative to pollen from gymnosperms. This is particularly true of pollen grains of gymnosperms which are carried by the wind.

The flora found in sediments from Site 368 differs from the Late Cretaceous and early Paleogene floras of the tropical zone discussed in the literature. These assemblages are also different from the floras of Late
Cretaceous to early Paleogene age from the Euramerian ("Norma"), Beringian ("Aquila") and Central Atlantic (Proxaperites-Proteaceae) which have been discussed by Vakhrameev et al. (1970) and Muller (1970). The main part of the taxa (Psilotricolpites operculatus V.d. Hammen, Euphorbia cf. hypericifolia, Retitricolporites chubutensis, some species of the Phyllanthus Zone and family Sonneratiaceae and Florchuetzia bombacacites is assigned an age younger than the early Paleogene (Danian-Paleocene). The palynocomplex can be correlated to palynozones B-D suggested by Van der Hammen and Wijmstra (1964) for the late Paleocene to Eocene of British Guiana and palynozones Retibrevitricolporites triangulatus and Psilatricolporites operculatus-Reticolpites gaianensis established by Hermeraad et al. (1968) for the late Paleocene and Eocene of the tropics, particularly for the regions of the Caribbean and western margins of Africa. However, the palynocomplex also contains components from the Florschuetzia levipoli Zone whose age in the Kalimantan region is middle Eocene.

It is evident that the exact age of the flora cannot be determined by studying only one sample. Nevertheless, the Paleogene (likely Eocene) age of the palynocomplex is beyond doubt. The same conclusion is likely to follow from an analysis of phytomicroplankton, the complex of which contains species of Microhistridium. Systematophora, Hystrichosphaera, among many others. They are known from late Paleocene and Eocene sediments from the equatorial and subequatorial zones.

A systematic study of the whole section will enable a series of correlative pollen taxa to be established and their changes in the chronological succession to be followed.

\section{REFERENCES}

Hermeraad, J., Hopping, G., and Muller, J., 1968. Palynology of tertiary sediments from tropical areas: Rev. Palaeobot. Palynol., v. 6, p. 189-348.

Muller, J., 1970. Palynological evidence on early differentiation of angiosperms: Biol. Rev., v. 45, p. 417-450.

Vakhrameev, V., Dobruskina, I., Zaklinskaja, E., and Meyen, S., 1970. Paleozoic, and mesozoic floras of Eurasia and phytogeography of this time: Tr. Geol. Inst. Acad. Sci. USSR, v. 208, p. 102-331.

Van der Hammen, Th. and Wijmstra, T., 1964. A palynological study on the Tertiary and Upper Cretaceous of British Guiana: Leidse Geol. Neded., D 30, p. 183-241. 


\section{PLATE 1}

Figures 1-5, 8 Sonneratiaceae

1, 2. Sonneratia sp.? cf. $S$. alba Backer

3, 4, 5. ? S. cf. griffitii Kurz.

Figures 6,7 Sonneratia cf. alba Backer

Figure 9 Ulmoideipites sp.

Figure $10 \quad$ Foveotricolporites corynoides Wijmstra

Figure 11 Liliacidites crassibaculatus Archangl.

Figures 12-14 Moraceae

12. Morus sp.

13, 14. gen. et sp. indet.

Figure 15 Bombax sp.

Figure 16 Gramineae (gen. et sp. indet.)

Figure 17 Euphorbiaceae (cf. Blumeodendron sp.)

\section{PLATE 2}

Figures 1-4 Rhizophoraceae (Rhizophora sp.)

Figures 5-7 Euphorbiaceae (Euphorbia sp.)

Figures 8-15 Euphorbiaceae

8, 9. Psilatricolporites colpiconstriatus HoeckenKlink.

10-12. Phyllanthus sp.

13. Alhornea sp.

14, 15. Psilatricolporites operculatus Van der Hammen.

Figure 16 Combretaceae (Psilotricolporites minutus Van der Hammen)

Figure 17 Rubiaceae (Coffea sp.)

Figures 18,19 Sapindaceae (cf. Lepisanthes)

Figure 20 Tricolpitepollenites baculiferus $\mathrm{R}$. Pot.

Figure $21 \quad$ Retistephanocolpites regularis Hoecken Klink.

(see page 936) 
PLATE 1

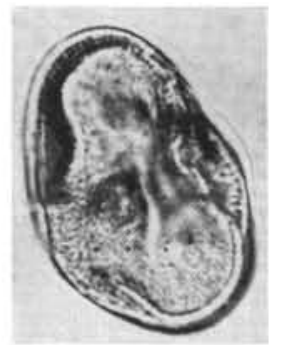

1

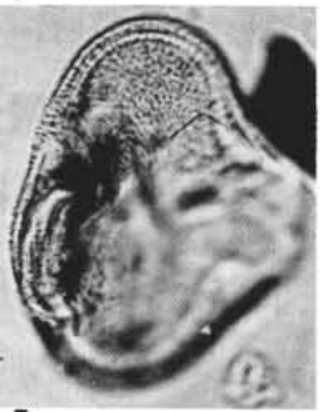

5
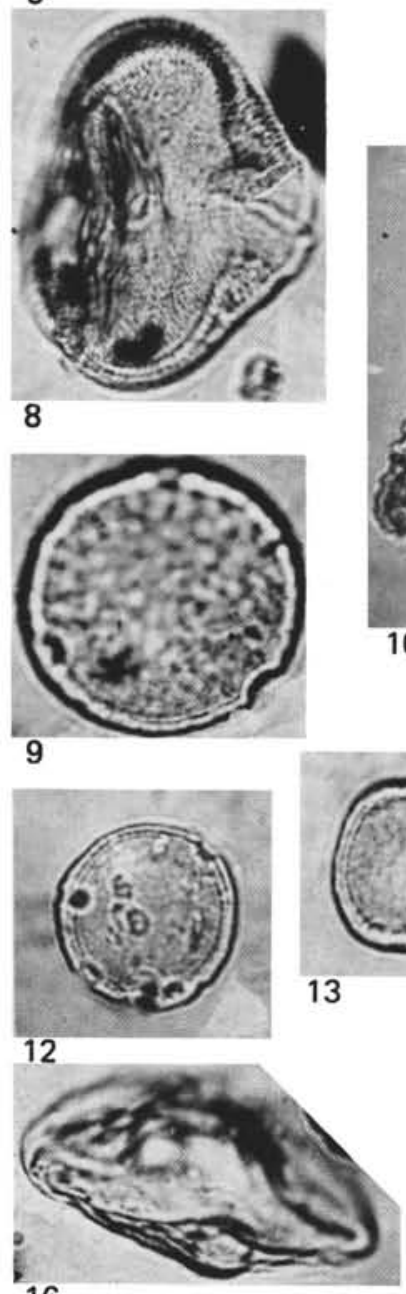

16

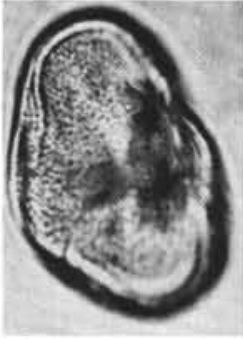

2
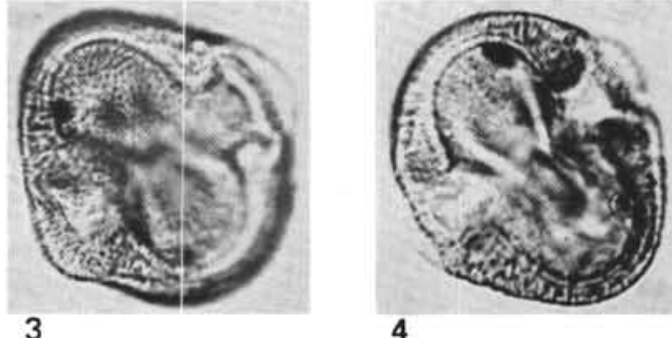

4

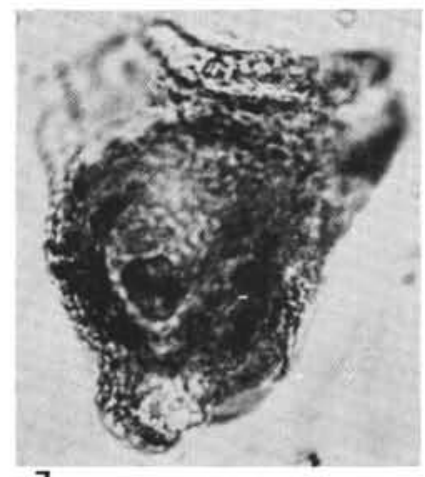

6
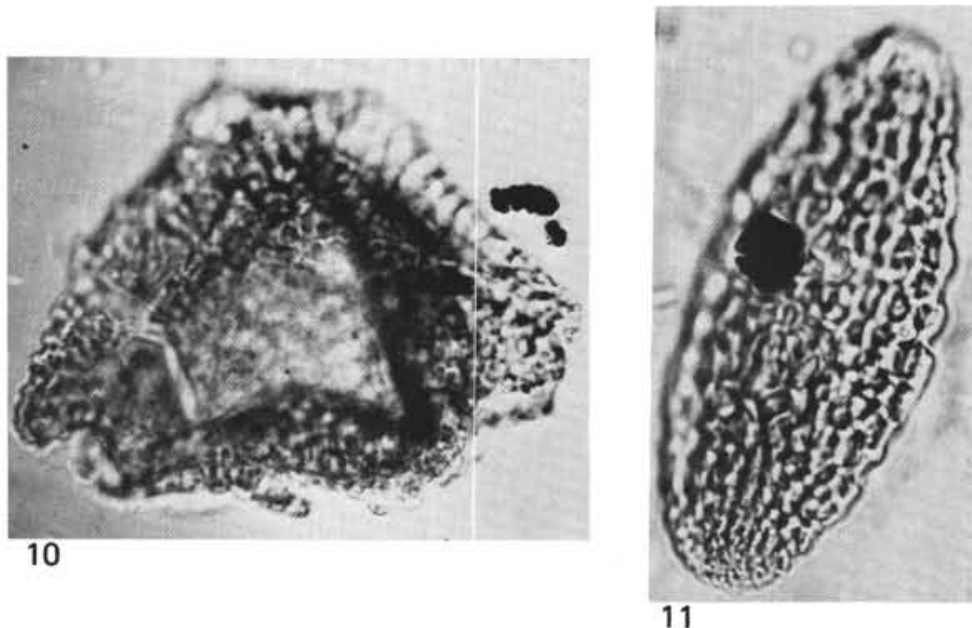

11
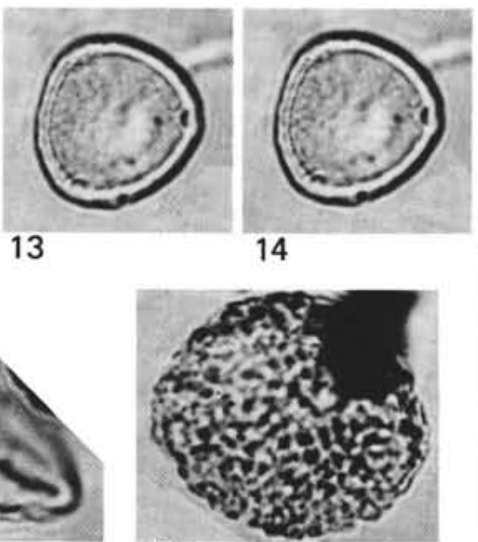

17

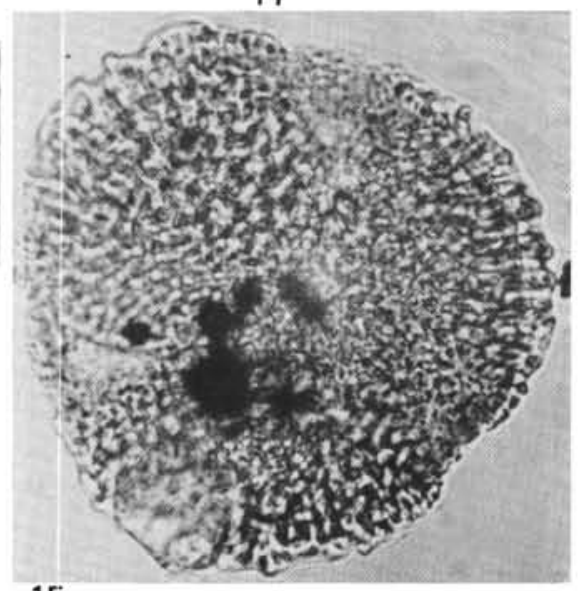

15 
PLATE 2
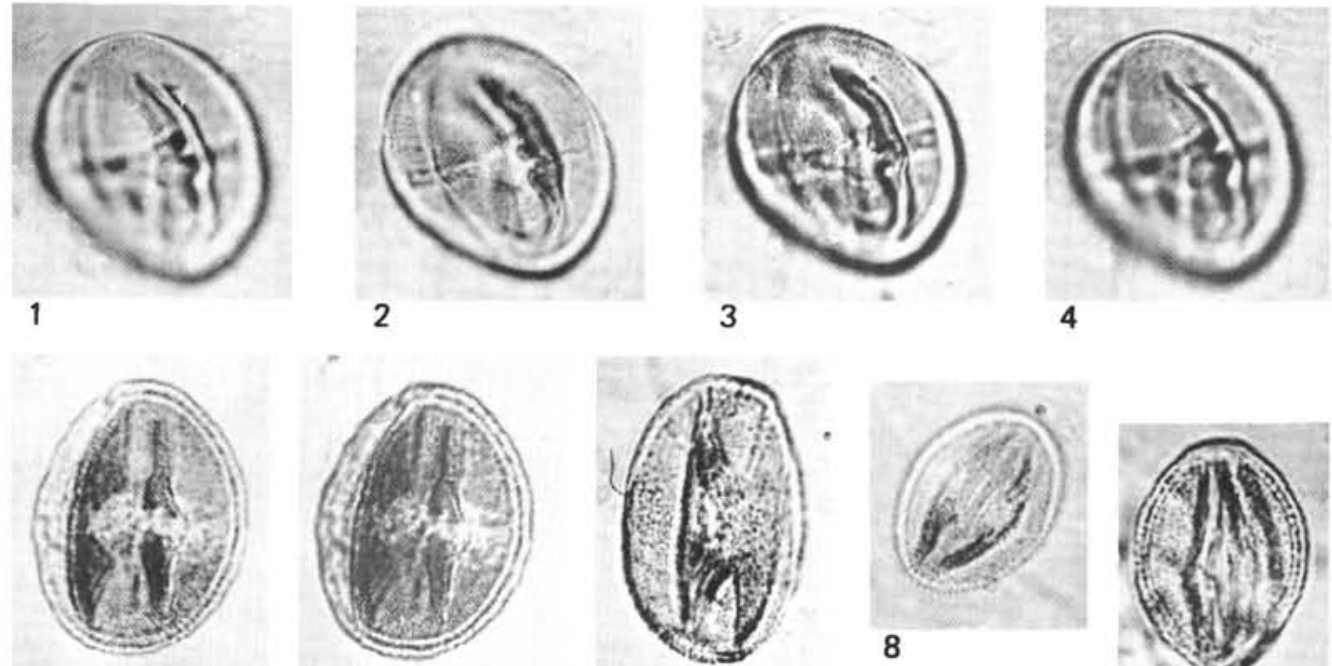

5
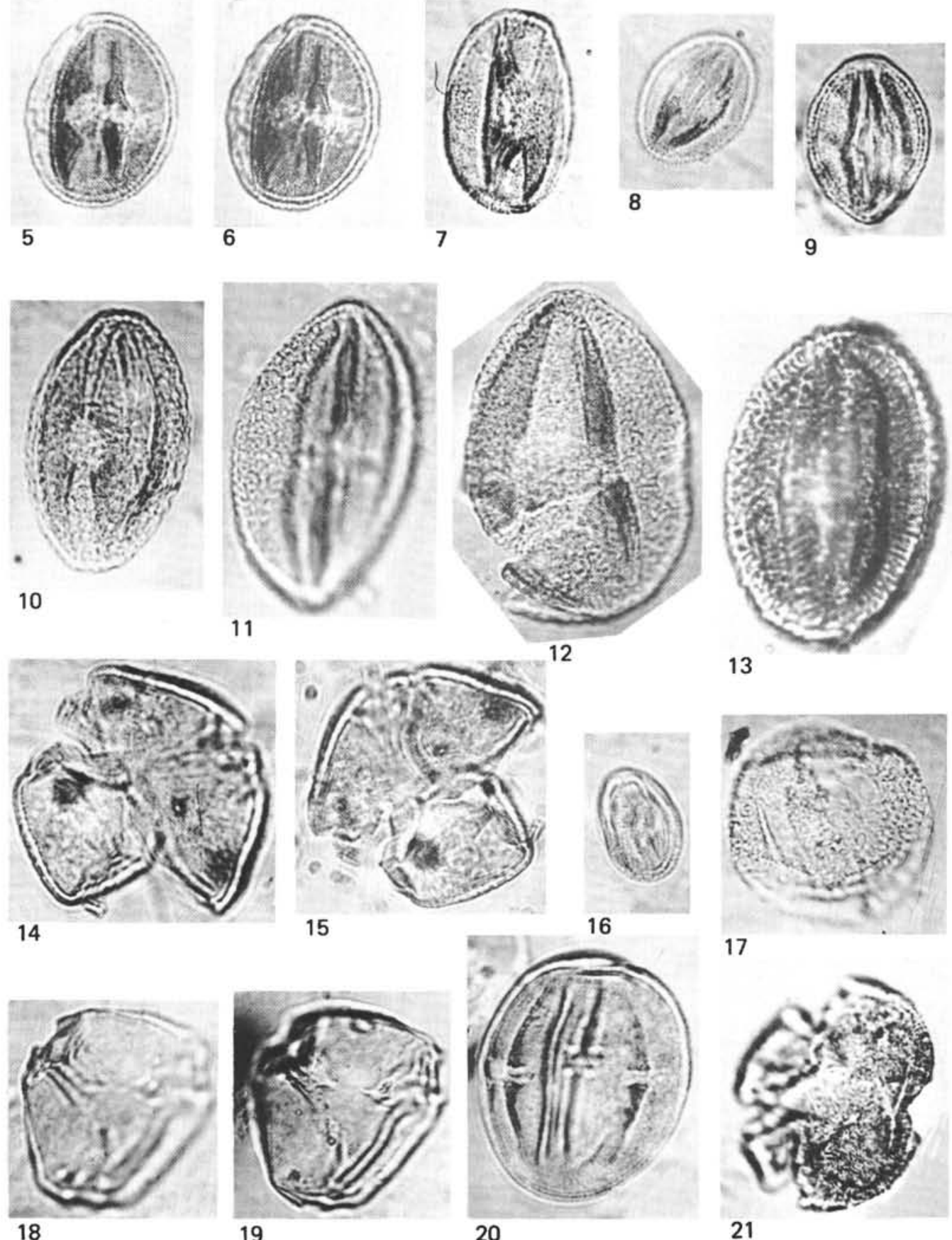

19
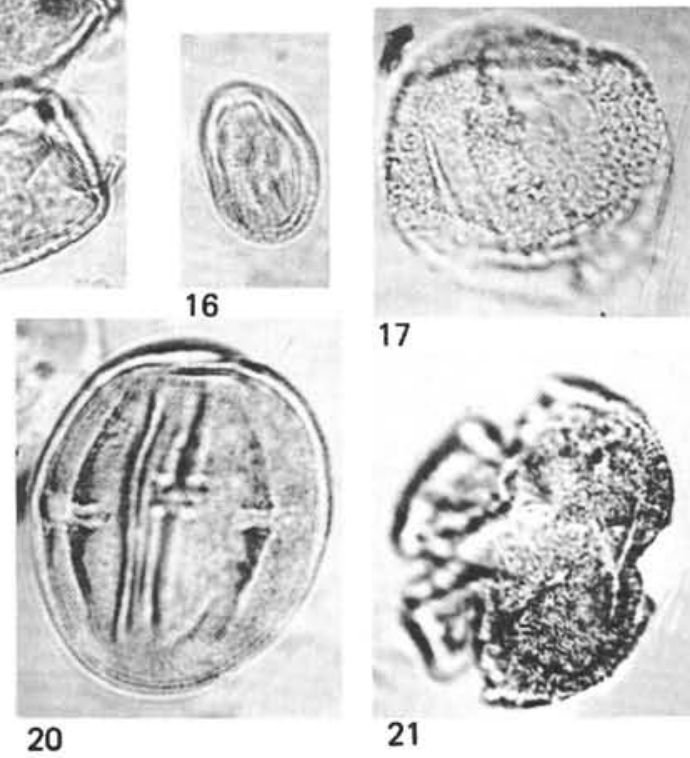

17

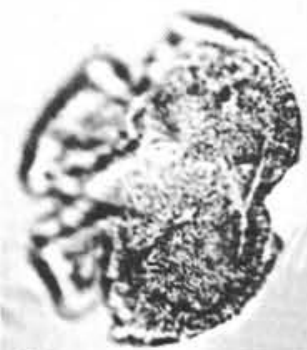

21 
PLATE 3
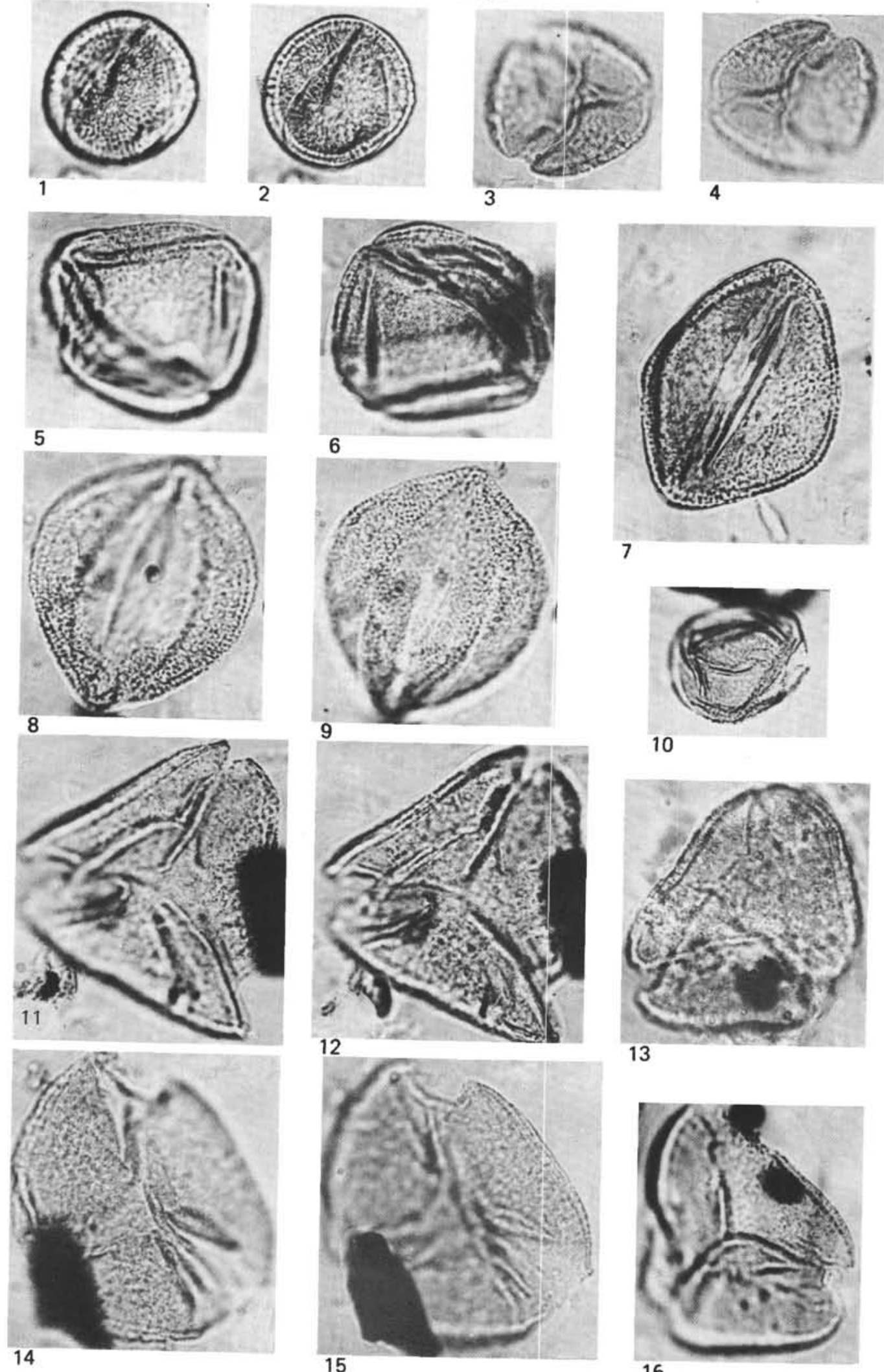

Figures 1, 2

15

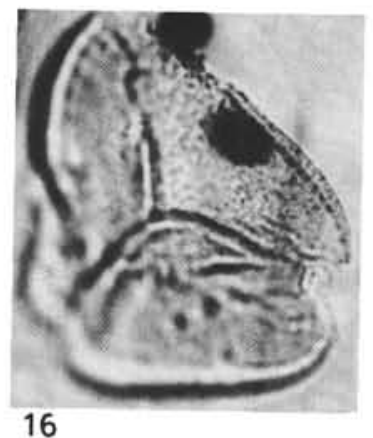

Figures 3, 4, 11-16

Retitricolpites $\mathrm{sp}$.

Figures 5, 6

Figures 7-9

Figure 10

Sapindaceae (gen. et sp. indet.)

Lecydiaceae (Psilatricolpites lecythioides Archangl.)

Retitricolpites nitidus Wijmstra

Angiospermae indet. 